\title{
Can we sustain health spending?
}

\section{Australian governments currently spend relatively little on health. Are cutbacks really what's needed?}

T

he assertion that health spending is unsustainable has been made with remarkable regularity, most recently by the Federal Minister for Health, Peter Dutton. ${ }^{1}$ Despite publication of a major review by the National Health and Hospitals Reform Commission ${ }^{2}$ less than 5 years ago, the Minister has called for a farreaching debate about the health system. ${ }^{3}$ Consistent with the rhetoric, the recent federal Budget has introduced copayments and foreshadowed cutbacks that are expected to reduce federal health spending by $\$ 8.6$ billion over the 4 -year forward estimates. ${ }^{4}$

The evidence usually cited to demonstrate the unsustainability of health spending is its impact on government finances. Between the 2001-02 and 2011-12 financial years, health expenditures by all levels of government rose from $19.8 \%$ to $25.6 \%$ of total tax revenues, ${ }^{5}$ and projections by the National Commission of Audit prior to the recent Budget suggested that federal spending alone could rise from $\$ 65$ billion in 2013-14 to over $\$ 120$ billion in 2023-24. ${ }^{6}$ These trends are commonly linked to the ageing of the population to conclude that significant structural reforms are needed to reduce spending on health services, and the recent budget measures may be seen as a first step in this direction.

Despite these projections, the unsustainability thesis is remarkably weak. Economies are flexible and the composition of spending varies significantly over time and between countries. At the time of federation, agriculture, manufacturing and the services sector accounted for $19 \%, 12 \%$ and $31 \%$ of gross domestic product (GDP), respectively. By 2011-12, the shares were $2 \%, 6 \%$ and $56 \%$, respectively. ${ }^{7}$ Technological change reallocates resources, and the expansion of industries is usually seen as desirable because it employs the displaced workforce and generates additional benefits. The anomalous concern with the costs and not the benefits of an expanding health sector implies comparative lack of concern or confidence in the benefits despite evidence that better health is one of the diminishingly few ways in which we can improve the quality of life of the population.

The flexibility of economic systems is also apparent when countries are compared. Australia currently devotes $9.5 \%$ of GDP to health, while the proportion in the United States has reached $17.7 \%$ (Box). The efficiency of the US health system may be questioned, but there is no suggestion that it has impaired the economy or sapped the vitality of the country.

The US case is interesting for another reason. Despite having the largest health expenditures in the world, when compared with the wealthy countries

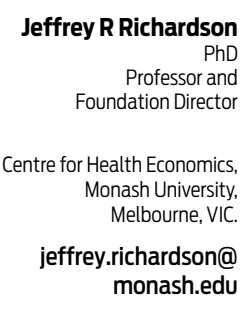

doi: 10.5694/mjal4.00564

of the Organisation for Economic Co-operation and Development (OECD) the proportion of the population above the age of 65 years in the US is the smallest. In contrast, the country with the oldest population Japan - spends little more than the OECD average on health. This illustrates a common error: the belief that health spending is tightly linked to the demographic structure and that ageing necessarily drives health expenditures. Historically, this has not been true, as health expenditures have been driven by technology and the increasingly generous provision of health services as GDP rises. ${ }^{12}$

Nevertheless, the pressure from ageing is likely to intensify. By 2050 the proportion of the population above 65 years of age in Australia is likely to rise from $14 \%$ to $22 \%$ and the proportion over 80 years to double from $4 \%$ to $8 \% .^{8}$ The pressure is likely to be exacerbated by expensive health technologies targeting individuals rather than broad disease categories. However, even with the slowing in the rate of per capita GDP growth to the average $1.4 \%$ per annum that occurred between 1970 and 1990, by 2050 GDP per capita will expand by $65 \%$. Even if total health expenditures rose to the US level of $17.7 \%$ of GDP there would be an expansion of non-health-related per capita GDP of $50 \%$, which could be devoted to the improvement of the material standard of living. This is not a paradox. Even if GDP grows more slowly than health expenditures, the absolute (not percentage) increase will be greater than the absolute increase in health expenditures. A 65\% rise in GDP from a (index) base of 100 will increase resources by 65 points. A $200 \%$ rise in health expenditures from a (index) base of 9.5 increases resource use by 19 points. Resources for other uses would rise by 46 points. Given the evident sustainability of health spending for some decades, it might be asked why health has been targeted for cutbacks. At $6.6 \%$ of GDP, public health expenditures by all governments in Australia are the tenth lowest of the 33 countries in the OECD database and the lowest among wealthy countries in the group (Box). Even US governments, which channel $8.3 \%$ of GDP into public health programs, outspend Australian governments. Further, as indicated in the Box, Australia has been relatively successful in restraining the growth of health spending.

A possible reason for the Minister's concern is that, irrespective of comparative statistics, health spending in Australia - or public health spending in particular may be inefficient. For example, a survey by Runciman and colleagues ${ }^{13}$ found that compliance with indicators of appropriate care was highly variable as judged by a retrospective review of medical records and telephone interviews with at least 1000 Australians. However, neither this nor the many other problems with the organisation and provision of services are likely to be

Online first 26/05/14 
Health spending, older population and taxes for selected countries

\begin{tabular}{|c|c|c|c|c|c|c|c|}
\hline & \multicolumn{2}{|c|}{ Total health spending* } & \multirow[b]{2}{*}{$\mathrm{PP}$ increase } & \multicolumn{2}{|c|}{ Public spending } & \multirow{2}{*}{$\begin{array}{c}\text { Population aged } 65+* \\
2011 \text { (\% total) }\end{array}$} & \multirow{2}{*}{$\frac{\text { Taxes }^{\dagger}}{2012(\% \text { GDP })}$} \\
\hline & 1980 (\% GDP) & 2011 (\% GDP) & & $2012\left(\%\right.$ total $\left.^{\ddagger}\right)$ & 2011 (\% GDP & & \\
\hline Australia & $6.1 \%$ & $9.5 \% * *$ & 3.4 & $69.7 \% * *$ & $6.6 \% * *$ & $13.7 \%$ & $26.5 \%{ }^{\dagger \dagger}$ \\
\hline France & $7.0 \%$ & $11.6 \%$ & 4.6 & $76.9 \%$ & $8.7 \%$ & $17.1 \%$ & $45.3 \%$ \\
\hline Canada & $7.0 \%$ & $11.2 \%$ & 4.2 & $70.1 \%$ & $7.4 \%$ & $14.7 \%$ & $30.4 \%$ \\
\hline Japan & $6.4 \%$ & $9.6 \%$ & 3.2 & $82.5 \%$ & $7.8 \%$ & $23.3 \%$ & $28.6 \%$ \\
\hline Sweden & $8.9 \%$ & $9.5 \%$ & 0.6 & $81.7 \%$ & $7.7 \%$ & $19.3 \%$ & $44.2 \%$ \\
\hline Netherlands & $7.4 \%$ & $11.9 \%$ & 4.5 & $79.8 \%$ & $9.5 \%$ & $15.9 \%$ & $38.6 \%$ \\
\hline United Kingdom & $5.6 \%$ & $9.4 \%$ & 3.8 & $82.5 \%$ & $8.1 \%$ & $16.2 \%$ & $35.7 \%$ \\
\hline United States & $9.0 \%$ & $17.7 \%$ & 8.7 & $46.4 \%$ & $8.3 \%$ & $13.2 \%$ & $24.0 \%$ \\
\hline OECD & $6.6 \%$ & $9.3 \%$ & 2.7 & na & na & $15.4 \%$ & $34.1 \%$ \\
\hline
\end{tabular}

$\mathrm{GDP}=$ gross domestic product. $\mathrm{PP}=$ percentage point. $\mathrm{OECD}=$ Organisation for Economic Co-operation and Development. na = not applicable. AlHW = Australian Institute of Health and Welfare.

* OECD. ${ }^{8}+$ OECD. ${ }^{9} \ddagger$ World Bank. ${ }^{10}$ q OECD. $11 * *$ AlHW. ${ }^{5}+\nmid 2011$ figure, as 2012 figure was not available.

spending. Both options would increase pressure for private health insurance (PHI) to cover the gap, and there is little or no evidence that private insurers would be more willing than the public sector to undertake the reforms needed to improve the quality of care. In principle, managed care might be used by private health insurers to achieve this goal, but the evidence of its success is limited and it appears unlikely that this is an option that Australian governments would be prepared to pursue, at least in the short run.

It is possible that copayments are seen as a way of controlling total costs; however, the effect of the recent budgetary measures on economic costs - resource use - will be miniscule. Evidence unequivocally indicates that copayments have a relatively small effect on service use. The $\$ 6$ copayment initially proposed by the Australian Centre for Health Research ${ }^{14}$ was estimated to reduce service use sufficiently to save $\$ 750$ million over 4 years - $0.3 \%$ of federal health spending, $0.14 \%$ of total health spending. The greater part of the 4-year federal budgetary saving of $\$ 5.5$ billion on Medicare Benefits Schedule items and \$866 million from the Pharmaceutical Benefits Scheme will therefore be a result of cost shifting to the public, not reduced service use. However the burden of private spending falls unevenly on the public: it self-evidently falls on the sick. Bulk-billing primarily assists those who are on a low income. The principle effect of its elimination will be a redistribution of income from this group to the healthier, wealthier members of the community. Copayments will, additionally, divert patients from lower-cost general practitioner care to higher-cost outpatient care. Those who defer needed treatment are likely to eventually need more expensive specialist care.

Perversely, in the longer run, eliminating bulkbilling is likely to increase GP fees and expenditures by reducing competitive pressures. An increase in the copayment from $\$ 7$ to $\$ 10$ is less likely to adversely affect an individual GP practice than the cessation of bulk-billing and the initial introduction of a copayment. Inflation of fees will be accelerated when the government succumbs to pressure to allow PHI to cover the widening gap. Increased GP fees may be independently desirable given the low level of GP incomes - the lowest relative to average wages listed by the OECD after Estonia and Hungary. However, a more equitable remedy would be to increase, not decrease, the rebate.

Reduced budgetary expenditures are not a necessary response to unsustainable spending or a solution to demonstrated inefficiencies. Rather, they are a response to budgetary pressures arising from inadequate tax collections and the failure of successive governments to implement suggested reforms. The $26.5 \%$ of GDP raised by all forms of taxation in Australia in 2012 was the fourth lowest of the 34 OECD countries after Chile, Mexico and the US. Proportionally, Northern European countries collect $40 \%-75 \%$ more than Australia. The result of lower taxation is lower levels of community services and infrastructure, and a long-term structural problem for government finances - outcomes which are strikingly evident in the US.

The damage to be inflicted on the health sector by reduced public spending is part of the price Australians will pay for the persistent failure of government to address this problem and to raise taxation to a level that allows improvement in the economic infrastructure, better community services and spending on all of the health services which - after careful evaluation - have been shown to provide cost-effective health benefits to the Australian community.

Competing interests: No relevant disclosures.

Provenance: Commissioned; externally peer reviewed.

1 Dutton P. Strengthening Medicare [media release]. 13 May 2014. http://www.health.gov.au/internet/budget/publishing.nsf/content/ budget2014-hmedia02.htm (accessed May 2014).

2 National Health and Hospitals Reform Commission. A healthier future for all Australians: final report June 2009. Canberra: Department of Health and Ageing, 2009. http://www.health.gov.au/internet/nhhrc/publishing. nsf/content/nhhrc-report (accessed Aug 2009).

3 Health minister flags increasing healthcare costs. 7.30 [television program]. Australian Broadcasting Corporation, 2014; 19 Feb. http://www. abc.net.au/7.30/content/2013/s3948295.htm (accessed Apr 2014).

4 Department of Health. Health - 2014-15 Budget at a glance. Canberra: Australian Government, 2014. http://www.health.gov.au/internet/budget/ publishing.nsf/Content/budget2014-glance.htm (accessed May 2014).

5 Australian Institute of Health and Welfare. Health expenditure Australia 2011-12. Canberra: AlHW, 2013. (AlHW Cat. No. HWE 59; Health and Welfare Expenditure Series No. 50.) http://www.aihw.gov.au/publicationdetail/?id=60129544658 (accessed Apr 2014).

6 National Commission of Audit. A pathway to reforming health care. In: Towards responsible government: the report of the National Commission 
of Audit, phase one. Canberra: Australian Government, 2014. http://www. ncoa.gov.au/report/phase-one/part-b/7-3-a-pathway-to-reforminghealth-care.html (accessed May 2014).

7 Trewin D. Year Book Australia, 2005. Canberra: Australian Bureau of Statistics, 2005. (ABS Cat. No. 1301.0.) http://www.abs.gov.au/ AUSSTATS/abs@.nsf/Lookup/1301.0Main+Features12005?OpenDocume nt (accessed Apr 2014).

8 Organisation for Economic Co-operation and Development. Health at a glance 2013: OECD indicators. OECD Publishing, 2013. http://www.oecd. org/els/health-systems/health-at-a-glance.htm (accessed Apr 2014).

9 Organisation for Economic Co-operation and Development. Total tax revenue. Taxation: key tables from OECD, No. 2. 2014. http://dx.doi. org/10.1787/taxrev-table-2013-1-en (accessed Apr 2014).

10 The World Bank. 2014 people. World development indicators: health systems. Table 2.15. http://wdi.worldbank.org/table/2.15 (accessed Apr 2014)
11 Organisation for Economic Co-operation and Development. Public health spending. Social Issues: key tables from OECD, No. 4. 2013. http://dx.doi. org/10.1787/healthxp-table-2013-1-en (accessed Apr 2014).

12 Richardson J, Robertson I, Hobbs M, Edwards D. The impact of new technology on the treatment and outcome of acute myocardial infarction in Australia. In: McClellan MB, Kessler DP, editors. Technological change in health care: a global analysis of heart attack. Ann Arbor, Mich: University of Michigan Press, 2002.

13 Runciman WB, Hunt TD, Hannaford NA, et al. Care Track: assessing the appropriateness of health care delivery in Australia. Med J Aust 2012; 197: 100-105.

14 Barnes T. Price signal of $\$ 6$ is fair for world-class healthcare. The Australian 2014; 1 Jan. http://www.theaustralian.com.au/national-affairs/ opinion/price-signal-of-6-is-fair-for-worldclass-healthcare/storye6frgd0x-1226792700135\# (accessed May 2014).

A wealth of experience.

One Disease healthy skin expert Wayalwanga Marika. East Arnhem Scabies Control Program, page 644 (C One Disease)
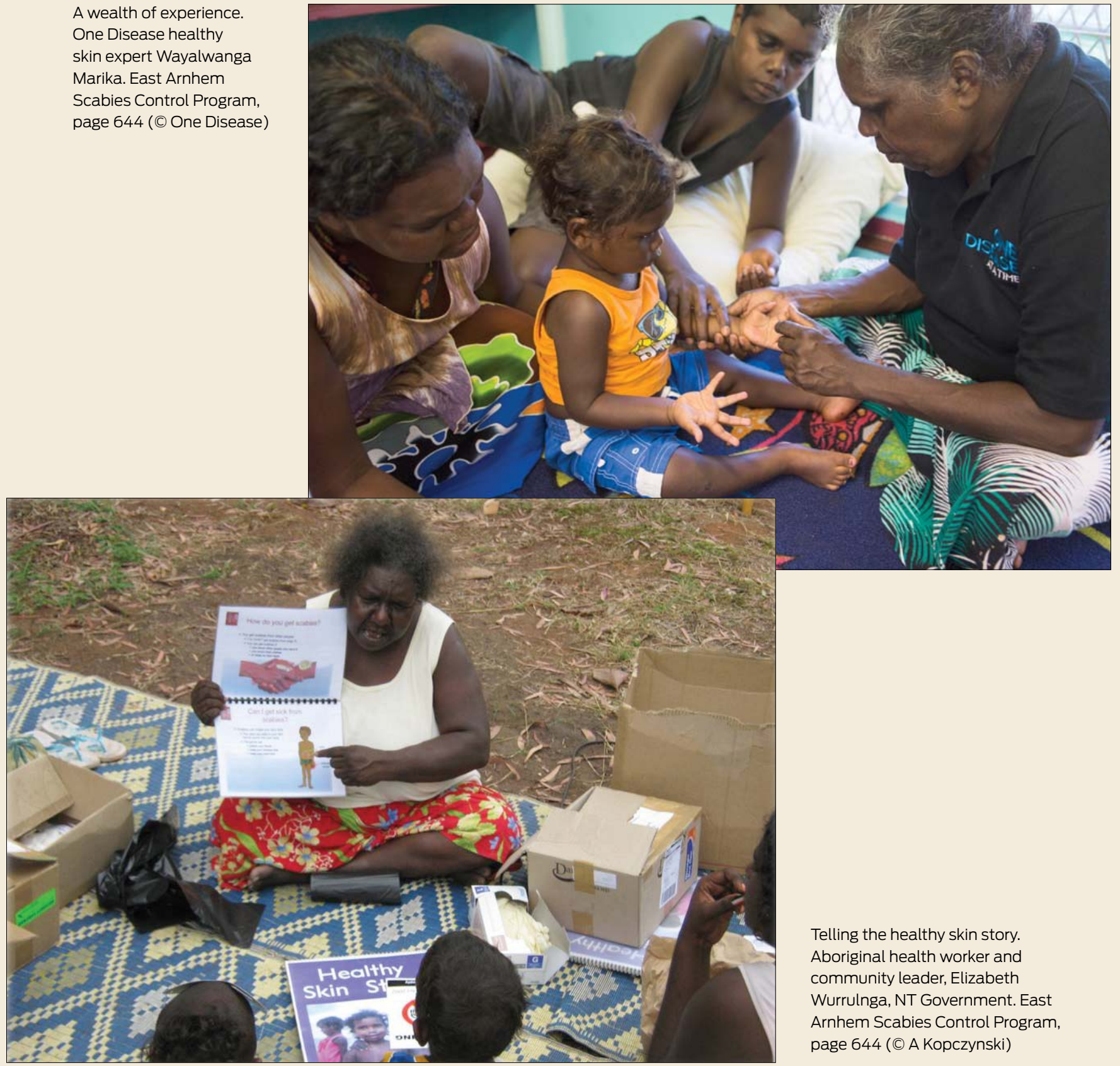

Telling the healthy skin story. Aboriginal health worker and community leader, Elizabeth Wurrulnga, NT Government. East Arnhem Scabies Control Program, page 644 (C A Kopczynski) 